MYKOLO ROMERIO
UNIVERSTIEAS

\title{
SUBSIDIARUMO PRINCIPAS KAIP PRIEMONE CIVILIZACIJŲ TAPATUMUI SUVOKTI
}

\author{
Virginija Kondratienè \\ Kazimiero Simonavičiaus universiteto Teisès fakulteto \\ Teisès katedra \\ Kauno g. 34, Vilnius, Lietuva \\ Telefonas (+370 5) 2135172 \\ Elektroninis paštas Virginija.atp@gmail.com \\ Pateikta 2012 m. spalio 18 d., parengta spausdinti 2013 m. liepos 21 d. \\ doi:10.13165/SMS-13-5-3-01 \\ Anotacija. Straipsnyje aptariama subsidiarumo principo reikšmè globaliu procesų regu- \\ liavimui, nagrinejamas subsidiarumo kaip fundamentalaus Europos Sajungos teises principo \\ vaidmuo civilizaciju tapatumui suvokti bei jo ịtaka politiniu-teisiniu sistemu funkcionavi- \\ mui. Straipsnyje akcentuojama šio principo svarba europiniam tapatumui išsaugoti, atsklei- \\ džiama subsidiarumo idejjos reikšmè Vakaru ir Rytu civilizacijoms priskiriamu bendruome- \\ niu teisinei samonei ir socialiniam ju susitvarkymui. Straipsnyje siekiama pagristi, kad siuo \\ principu paremti teisinio reguliavimo mechanizmai neleidžia globaliai sistemai nepaisyti \\ civilizaciju skirtumu, o lokaliam identitetui sugriauti pasaulio vienoves, todel greta unifi- \\ kuotu socialiniu sistemu gali koegzistuoti savitą organizacinę struktūrą, kultūrines tradicijas \\ ir vertybines nuostatas turintys nacionaliniai, regioniniai ar lokalüs autonominiai dariniai.
}

Reikšminiai žodžiai: civilizacijų skirtumai, Europos tapatumas, subsidiarumo principas, socialiniu sistemu teisinis reguliavimas. 


\section{Ivadas}

Globalioje aplinkoje socialinė, politinè ir ekonominė žmonių veikla dažnai peržengia valstybių, regionų ar žemynų ribas, o intensyvejjantys ryšiai verčia ieškoti naujų formų teisiniams santykiams reguliuoti, kad jie netaptų kliūtimi tenkinant nuolat kintančius socialinius-ekonominius ar kultūrinius globalios visuomenès poreikius. Vadinasi, visame pasaulyje vykstančios permainos - globalizacijos procesai, daro tiesioginị poveikị konkrečios visuomenès teisinei sąmonei ir socialiniam jos susitvarkymui. Politinių teisinių sistemų unifikavimas kelia grèsmę nacionalinių valstybių ir regionų identitetui, pasaulio kultūroms, jų formų ịvairovei. Neatsitiktinai Europoje, kaip ir kitose pasaulio civilizacijose, tapatybès išsaugojimo klausimas kaip niekad aktualus, nors ir pripažįstama, kad ,globalių ryšiu susaistytame pasaulyje nè viena tauta negali išvengti globalizacijos poveikio". Taigi, norime mes to ar ne, tačiau turime pripažinti, kad visame pasaulyje vykstančios permainos yra neišvengiamos, o globalizacija turètų (galètų) būti ,traktuojama kaip objektyvia realybę atspindintis désningumas ${ }^{\text {“2 }}$ arba „kaip esminis požymis, charakterizuojantis tiek šiuolaikinę visuomenę bei jos gyvenima, tiek šiuolaikinei visuomenei būdingus pokyčius, raidos ir pažangos reiškinius ir procesus ${ }^{\text {“3 }}$. Kartu turetume pripažinti ir tai, kad globalizacijos procesai ir teisinių sistemų unifikavimas neišvengiamai provokuoja civilizacijų susidūrimą, todèl skatina imtis kartais pernelyg drastiškų priemonių tautiniam, kultūriniam ar valstybių identitetui apsaugoti. Šiai priešpriešai sušvelninti ir civilizacijų susidūrimui išvengti subsidiarumo principas ${ }^{4}$ yra tinkamiausia priemonè. Šiuo principu paremti teisinio reguliavimo mechanizmai neleidžia globaliai sistemai nepaisyti civilizacijų skirtumų, o lokaliam identitetui sugriauti pasaulio vienovès, todèl greta unifikuotų socialinių sistemų gali koegzistuoti savitą organizacinę struktūrą, kultūrines tradicijas ir vertybines nuostatas turintys nacionaliniai, regioniniai ar lokalūs autonominiai dariniai. Pripažįstant subsidiarumo principo nemenkas (dažnai pranokstančias bet kurio kito principo) galimybes ịvairiems procesams, sistemoms ir santykiams reguliuoti, svarbu suvokti ir tai, kad „nè vienas principas, nè viena idèja negali realizuotis iki galutinių savo konsekvencijų. Principų gyvenime visados daug ir gyvenime jie nèra vienas kitam priešingi, kaip jie

1 Astrauskas, R. Etninès kultūros subjektų teisių apsauga. Etninè kultūra. 2004, 3: 31.

2 Melnikas, B. Regionalizmo procesai globalizacijos sąlygomis. Viešasis administravimas. 2011, 3 (31): 39.

$3 \quad$ Ibid.

4 „Politologine prasme subsidiarumas - tai politinių sistemų valdymo principas, padedantis nustatyti politinio darinio teisinį statusą, organizacinę struktūrą bei jo sąveiką su kitais autonominiais dariniais politinių organizacijų sistemoje. <..> Subsidiarumas - tai demokratinių valdymo sistemų teisinio reguliavimo principas, kuriuo pasiekiamas valdžios galių balansas, kompetencijų atribojimas valstybès, regioninio ar vietos lygmens institucijose ir sprendimų prièmimas žemiausioje valdymo grandyje (arčiausiai piliečių), tuo būdu sukuriant teisines prielaidas veiksmingai igyvendinti asmens teises ir jų apsaugą bet kuriame valstybès valdymo ar vietos savivaldos lygiu. Subsidiarumo principas teisejje bréžia prioritetinę pozityviosios teisès normų kryptị, kurių turinys paklūsta prigimtinės teisės vertybiniam autoritetui, pozityviajai teisei keliančiam moralumo ir teisingumo reikalavimus, ir ją determinuoja universalių teisinių vertybių (pagrindinių žmogaus teisių) bei socialinių būties poreikių realizavimui." Kondratienè, V. Subsidiarumo principas ir jo taikymas valstybès valdymui ir vietos savivaldai. Daktaro disertacija. Socialiniai mokslai, teisè. Vilnius: Mykolo Romerio universitetas, 2011, p. 36-37. 
atrodo dialektiškoje abstrakcijoje. Politikoje yra didelis menas mokèti tuos principus derinti ir tarp jų laviruoti“‘s. Šis žymaus tarpukario Lietuvos ekonomisto Domo Cecevičiaus požiūris tik dar kartą patvirtina, kad vieno recepto, kaip ir kokiais principais vadovaujantis reguliuoti socialines žmonių bendruomenes, negali būti jau vien todèl, kad „kintanti aplinka ir kintantys visuomenès santykiai diktuoja savitus jų reguliavimo mechanizmus, priklausomai nuo to, kokie prioritetai visuomeneje dominuoja, kokie poreikiai ir interesai juos iškelia ir priverčia įgyvendinti. Vis dèlto nuneigti subsidiarumą, kaip šiuolaikinès visuomenès socialinę ir etinę vertybę, reikštų nuneigti vienovės, ịvairovès ir harmonijos reikšmę pasaulio bendruomenei, be kurių žmonijos egzistavimas yra neįmanomas, būtent todèl subsidiarumas tampa šios bendruomenès būties ir jos išlikimo esmine substancija." "6 Šiai problematikai nagrinèti - civilizacijų tapatumui suvokti bei ju „,sugyvenimui“ paskatinti ir yra skirtas minètas tyrimas. Straipsnyje keliamas tikslas - pagrịsti subsidiarumo principo panaudojimo galimybes civilizaciju identitetui ir skirtybėms atskleisti, kartu pagrindžiant subsidiarumo kaip Europos bendruomenę vienijančios idèjos reikšmę išsaugant Europos identitetą bei kuriant Europą vienijančias struktūras, kurių reikšmingiausia laikytina Europos Sajunga, paskatinusi ir unikalios Europos Sajungos teisinès sistemos atsiradimą. Straipsnis aktualus mokslininkams, savo tyrimuose akcentuojantiems Europos tapatybės bei vienovės ịvairoveje idèją, taip pat jis turètu būti ịdomus ir platesniam visuomenès ratui, besidominčiam civilizacijų įtaka globalizacijos procesams bei visuomenès organizacijų susidarymui. Straipsnyje, remiantis civilizacijas tyrinèjančių mokslininkų (pvz., S. Hantingtono ${ }^{7}$ ) ịžvalgomis, ieškoma atsakymo ị klausimą, kokios priežastys skatina etninius, religinius ir karinius tautų, valstybių ar atskirų regionų konfliktus, kaip pasaulio bendruomenei išvengti civilizacijų susidūrimo. Bandoma paaiškinti, kodèl pasaulyje kylančių konfliktų priežastys glūdi ne ideologijoje ar ekonomikoje, o religiniuose ịsitikinimuose ir kultūriniuose skirtumuose, kodèl šiems tyrimams būtina skirti didesnị dėmesị.

Straipsnyje civilizacijų tapatumo kontekste tiriami ir politinių - teisnių sistemų organizavimo modeliai, atliekamas jų vertinimas pažangos požiūriu - socialinės santvarkos atitiktis visuomenès poreikiams. Tyrime iš dalies polemizuojama su socialines sistemas ir jų bazinius institutus tyrinëjančiais mokslininkais (pvz., S. Kirdina ${ }^{8}$, L. Romanenko ${ }^{9}$ ), bandant pagrịsti, kad Vakarų civilizacija iš tiesų laikytina pažangesne žmonių socialinio gyvenimo organizacijos forma, nes ji, skirtingai nei centralizuotas Rytu visuomenès

5 Domas Cesevičius. Parengė V. Lukoševičius ir M. Treinys. Vilnius: Margi raštai, 1998, p. 115.

$6 \quad$ Kondratienè, V., supra note 4, p. 75.

7 Huntington, Samuel, P. The Clash of Civilizations and the Remaking of World Order. New York, Simon \& Schuster, 1996.

8 Kirdina, S. G. Institucionalnye matricy i razvitie Rossii [Institutional matrices and development of Russia]. Moskva: TEIS, 2000.

9 Romanenko, L. M. Socialnye technologii razreshenija konfliktov grazhdanskogo obshhestva: ekhzistencialnye alternativy sovremennoj Rossii na poroge tretego tysjacheletija [Social technologies in civil community conflict resolution: Existential alternatives in contemporary Russia on the brink of the third millennium]. Moskva: Centr konfliktologii In-ta sociologii RAN, 1998. Centr - regiony - mestnoe upravlenie [Centerregions-local authorities]. Pod red. Liuskhterkhandt-Mikhajlovoj, G. M.; Rizhinkova,S. I. Sankt-Peterburg, 2001. 
socialinis susitvarkymas, yra išimtinai paremta subsidiarumu, kuris Vakarų Europos politinès minties tradicijoje iškyla kaip humanistinè idejja, etinė ir socialinè vertybé $\dot{e}^{10}$, pastūmèjusi Vakarų visuomenes savo valstybinius darinius struktūruoti remiantis individų (turinčių savo pilietines ir politines teises ir laisves) teisinio bendravimo ${ }^{11}$ ir bendradarbiavimo principais, bei igijusios juose bendruomenès sutarties (chartijos) pagrindais besitvarkančios organizacijos formas. Pažymètina ir tai, kad subsidiarumo idèja turi gilias politinès-teisinès minties tradicijas Europoje, nes, anot K. Endo, šio principo apraiškų galima aptikti dar prieš šimtmečius publikuotuose politinès filosofijos veikaluose, o kai kurių analitikų teigimu, jis pradètas taikyti religijos filosofų dar XVI a. ${ }^{12}$ Subsidiarumo prigimties istorija taip pat siejama su antikos polių - miestų valstybių (senovès Graikijos) ir viduramžių Vakarų Europos miestų valdymo modeliais, grindžiamais visuomenès sutartimi ir savivalda, plačiai nagrinètais Aristotelio, Cicerono, J. Altuzijaus, D. Loko ir kt. Vèliau (XVII a.) šios idejos plètojamos ir H. Bulingerio valstybès suvereniteto teorijos doktrinoje, valdymo, ,iš apačios“ struktūroje. T. Akviniečio ir J. Altuzijaus darbuose subsidiarumas suprantamas kaip tautos suvereniteto įtvirtinimo ir skirtingų valdžios lygmenų institucionalizavimo valstybės organizacijoje idèja. Toks organiškai ir socialiai integruotas visuomenès organizacijos modelis tapo pagrindu federacinėms valstybėms Europoje kurti ir yra laikomas Europos Sajungos institucionalizavimo pamatu. Todėl nagrinėjant civilizacijų įtaką Europos tapatumo formavimuisi bei Europos valstybių vienijimosi procesus (kuriant Europos Bendrijos organizacijas, o vėliau įsteigiant ir Europos Sajungą), straipsnyje remiamasi tiek ankstesniais mokslinès minties šaltiniais, tiek ir šiuolaikinėmis mokslinėmis studijomis (pvz., jau minèto S. Hantingtono, S. Kirdinos, lietuvių mokslininkų B. Melniko, L. Donskio, Ž. Pavilionio, A. Andrijausko ir kt. ${ }^{13}$ ) bei politikų (pvz., Ž. Deloro, dar vadinamo Europos Sajungos architektu, A. Merkel ${ }^{14}$ ir kt.) mintimis. Minèti tyrimai padeda suvokti skirtingų teisinių sistemų atsiradimo Europoje prielaidas, Vakarų teisès tradicijos įtaka Vakarų visuomenès teisinei sąmonei ir socialiniam jos susitvarkymui. Taigi, šie ir kiti aspektai straipsnyje yra plètojami Europos tapatumo kontekste, pagrindinį dėmesi sutelkiant ị civilizacijų daromą įtaką skirtingų socialinių sistemų institucionalizavimui, kurių organizaciniams skirtumams atskleisti ir yra pasitelktas subsidiarumo principas.

10 Kondratienė, V., supra note 4, p.11.

11 Kostjuk, K. Byt li Rossii subsidiarnoj? [Will Russia become a subsidiary state?] [interaktyvus]. 2004 [žiūrèta 2009-05-10]. <www.novopol.ru/-byit-li-rossii-subsidiarnoy--text308.html>.

12 Endo, K. Subsidiarity and Its Enemies: To What: To What Extent Is Sovereignty Contested in the Mixed Common wealth of Europe? Florence: EUI, RSC Working Paper No. 2001/24, 2001.

13 Donskis, L. Kuo skiriasi lyginamujų civilizacinių studijų klasikai ir jų dabartinè banga. Baltos lankos. 1995, 6: 18-61; Pavilionis, Ž. Europos integracija ir civilizacijų susidūrimas. Politologija. 1999, 1 (13): 43; Andrijauskas, A. Metacivilizacinès kultūros metamorfozès ir globalizacijos prieštaravimai. Logos. Religijos, filosofijos ir meno žurnalas. 2001, 25: 16.

14 Merkel, A. Europos vertybės globaliame pasaulyje. Naujasis Židinys - Aidai. 2006, 1-2. 


\section{Subsidiarumo principas, globalizacijos procesai ir skirtingu civilizacijų sugyvenimas}

Subsidiarumo termino ịtraukimas į Europos Bendrijos ir nacionalinių valstybių teisę praplètė šio termino taikymo ribas. Subsidiarumas tapo fundamentaliu Europos Bendrijos teisès principu ir yra taikomas Europos Sajungos ir nacionalinių valstybių teisiniams santykiams reguliuoti. Kartu jis pripažintas universalia ir veiksminga priemone reguliuojant įvairaus lygio ir pobūdžio procesus bei valdymo sistemas tiek globaliu, tiek ir lokaliu mastu, kurị taikant siekiama išvengti globalaus ir lokalaus intereso susidūrimo, išlaikyti valdymo sistemų unifikavimo ir individualizavimo balansą atsižvelgiant tiek ị pasaulio, tiek ị konkrečios bendruomenès (individo) poreikius. Vertinant tai, kad globalizacija laikytina tam tikrų dėsningumų išraiška, nes globalizacijos procesai reiškèsi visais žmonijos raidos etapais, kas leidžia teigti, kad šiuolaikiniai globalizacijos procesai yra ne kas kita, kaip istoriškai susiklosčiusio reiškinio raiška dabartinio žmonijos raidos etapo sąlygomis, vadinasi, subsidiarumas, kaip globalių ir lokalių procesų, socialinių sistemų (civilizacijų sugyvenimo) derinimo instrumentas yra nuolatinis ir būtinas pasaulio bendruomenès palydovas, palaikant visumos ir atskirų jos struktūrinių elementų sąveiką ir ịvairovę vienovejje. Globalizacija ir identitetas, šios savo prigimtimi priešingos pagrindinès šiuolaikinio pasaulio vystymosi tendencijos daro tiesioginę ịtaką visuomenès raidai, provokuodamos politinio, socialinio, etninio, religinio bei kitokio pobūdžio visuomenès konfliktus. S. Hantingtonas, skirstydamas pasaulị ị tarpusavyje konkuruojančias civilizacijas, nurodo, kad civilizacijų varžymasis dèl religijų (krikščionybès, islamo, induizmo ir konfucianizmo ir kt.) yra neišvengiamas, o tai ir yra tikroji kylančių konfliktų priežastis. Su šiuo teiginiu negalima nesutikti. Didejjanti sąveika tarp tautu stiprina savo civilizacijos supratimą, priklausomybę jai ir skirtumo tarp civilizacijų jausmą, o kartu provokuoja ir jų susidūrimą: „civilizacinis identitetas nustato integracijos, dezintegracijos bei konfliktų rèmus šiuolaikiniame, po Šaltojo karo atsiradusiame pasaulyje. ${ }^{\text {"15 }}$ Kai kiekvienas etninis ar valstybinis darinys politine (ar karine) jèga siekia įtvirtinti savo pasaulinès tvarkos vizijas, civilizacijų konfliktas yra neišvengiamas. Vakaru siekis skleisti savo demokratines liberalizmo vertybes, ne visuomet atsisakant karinio dominavimo, skatina kitų etninių grupių nepasitenkinimą ir provokuoja „Vakaru ir kitu“ “ civilizacijų konfliktus ${ }^{16}$. Antrinant išsakytoms mintims, būtina pastebèti ir tai, kad minèti procesai lèmé spartesnị Europos valstybių vienijimąsi ir Europos Sajungos atsiradimą. Neatsitiktinai viename iš savo pasisakymų Vokietijos kanclere Angelina Merkel akcentavo, kad Europa vienydamasi nori apsaugoti savo gyvenimą ir savo laisvas visuomenes, kad jos būtų atviros, o kiti yra pasiryžę guldyti galvas, kad ši visuomenès būtų sunaikinta ${ }^{17}$. Todèl, anot jos, ,turime gerai pagalvoti, kaip deramai pasitikti šiuos iššūkius. $<\ldots>$ juos sutelktai gali pasitikti tik visa tarptau-

15 Hantingtonas Samuel, P., supra note 7, p. 20.

16 Kondratienè, V. Teisiniai socialinių sistemų institucionalizavimo aspektai. Viešasis administravimas. 2012, 2 (34): 72.

17 Merkel, A., supra note 14, p. 45. 
tinè bendruomenè. $<\ldots>$ mums būtina transatlantinè partnerystè, bendras demokratinių vertybių pagrindas. $<\ldots>$ Europa turi ne tik moralės požiūriu žinoti, kas darytina, bet ir būti pasiryžusi visur kur pati prisidèti ${ }^{\text {"18 }}$, t. y. subsidiariai ir solidariai veikti išsaugant taiką ir harmoniją pasaulio bendruomenèje. Apskritai galima teigti, kad skiriant nepakankamai dèmesio civilizacijų kultūriniams skirtumams pažinti ar juos pripažinti, kartu ignoruojami ir esami atskirų socialinių bendruomenių pažiūrų ir vertybinių nuostatų skirtumai, šių bendruomenių teisinè sąmonè ir teisès tradicija, asmens, kaip konkrečios visuomenès atstovo tapatumo, jo savasties pripažinimo reikšmè taikiam sambūviui ir dialogui tarp skirtingų žmonių, tautų ar valstybių palaikyti. Šiuolaikiniam pasauliui itin svarbu ne tik išsaugoti pasaulio bendruomenę vienijančias idejas, bet ir globaliame pasaulyje pripažinti egzistuojant civilizacijų skirtumus, kas neabejotinai prisidètų prie galimybių išvengti jų susidūrimo, paskatintų taikų civilizacijų sugyvenimą. Žanas Deloras viename iš pasisakymų akcentavo, kad Vakarai turi giliau pažinti religinius ir filosofinius kitų civilizacijų pagrindus, atrasti būdus ir priemones skirtybėms globalioje erdvejje išlaikyti bei jų priešpriešai išvengti. Čia atkreiptinas dèmesys ir ị tai, kad „Vakarų krikščioniškają ir Rytų islamišką civilizaciją, kurių visuomenių gyvenimas reguliuojamas skirtingais parametrais - pirmuoju atveju teise (teisès sampratoje, anot A. Vaišvilos, pabrèžiant ir būtiną teisès ir moralès santykị), antruoju - išimtinai religija (kai teisei patikima tik įsitikinimų ir pasaulěžiūros realizavimo funkcija) skiria didžiausia praraja ${ }^{\text {"19 }}$. Šių vertybinių orientacijų ir jų poveikyje besiformuojančių socialinių sistemų skirtumai reikalauja pažinti ir pripažinti (gerbti) kitų ịsitikinimus ir demokratinèmis priemonėmis ieškoti sąlyčio taškų. Neatsitiktinai „visuomenės vertybinių nuostatų sankirtoje subsidiarumo idèja tampa itin efektyvia priešybių derinimo, konfliktų sprendimo ir taikaus sambūvio formų paieškos priemone, padedančia sukurti visuomenès organizacijoje globalių ir individualių, universalių ir savitų, pastovių ir kintamų elementų sąveikos modelį. Subsidiarumo idejja derinant priešybes įsiprasmina kaip šios įvairovès kūrimo vienovejje principas, kuriuo užtikrinama visumą sudarančių autonominių darinių sąveika, globaliame pasaulyje išsaugant nacionalinius, regioninius, kultūrinius valstybių ir tautų savitumus“20. Subsidiarumo principas Europos bendruomenei dèl jo turimų savybių (valdžios galių, skirtingų pažiūrų ir interesų balansavimo) pasirodè itin veiksminga konfliktų reguliavimo priemone, skatinančia skirtingų civilizacijų dialogą ir demokratijos plètrą, mažinančia tautinị susipriešinimą, etninių, religinių ir karinių konfliktų tikimybę. Šis principas yra laikomas veiksmingu socialinių sistemų ir teisinių santykių reguliavimo instrumentu tiek vietos, regioniniu ar nacionaliniu lygmeniu, tiek ir Europiniu ar tarptautiniu mastu, todèl subsidiarumo principu paremti teisinio reguliavimo mechanizmai neleidžia globaliai sistemai nepaisyti civilizacijų skirtumų, o lokaliam identitetui - sugriauti pasaulio vienovès. Subsidiarumas, kaip priešybių derinimo ir jų balansavimo principas, palaiko sistemų pusiausvyrą, neleisdamas vienai kitą nustelbti ir sutrikdyti vyraujančios santykių harmonijos bei pasaulinès taikos. Vadinasi,

18 Merkel, A., supra note 14, p. 45.

19 Kondratienè, V., supra note 4, p. 41.

20 Ibid., p. 6. 
subsidiarumo principas yra tas instrumentas, kuriuo remiantis galima ištirti ne tik socialinių organizacijų, bet ir globalių sistemų, kurioms priskirtina ir civilizacija, funkcionavimą. Kitaip tariant, vadovaujantis subsidiarumo principu galima nustatyti civilizacijų požymius ir ypatybes, jų skirtumus, civilizacijų reikšmę konkrečių visuomenių teisinei sąmonei ir socialiniam jų susitvarkymu.

Kas gi yra toji civilizacija ir kodèl globalius procesus tyrinejantys mokslininkai kalba apie galimą (esamą) jų susidūrimą? Kokie būdai ir priemonès būtų tinkami pasaulio harmonijai palaikyti? Ar iš tiesų subsidiarumo principas yra tas instrumentas, kuriuo remiantis pasiekiamas interesų balansas, suteikiantis pačiai visuomenei galimybę atrasti veiksmingas savęs organizavimo ir jos poreikius igyvendinančias formas bei sukurti atitinkamas socialines struktūras ir jų veiklą reguliuojančius teisès institutus?

Paprastai socialinès organizacijos skirstomos ị panašius požymius turinčias politines-teisines sistemas, sociologijos moksle apibrėžiamas civilizacijos terminu. Civilizacijos sąvoka tirta ne viename moksliniame veikale, jos pagrindai suformuluoti prancūzų, plètoti anglų ir vokiečių mokslininkų (pvz., O. Spenglerio ${ }^{21}$ ) darbuose. Šiuolaikiniuose civilizacijų tyrimuose aktyviai dalyvauja ir Lietuvos mokslininkai ${ }^{22}$. Tiriant civilizacijas ir patiriant jų ịtaką susiformavusias politines-teisines sistemas, svarbu pasirinkti teisingą tyrimų atskaitos tašką. Pavyzdžiui, A. Andrijauskas civilizacijų lyginamųjų studijų išeities tašku pasirenka ne romantikų mitologijos idealizuojamą tautinę valstybę, o universalesnès prigimties nacionalumą peržengiančias civilizacijų konfigūracijas. Pasak jo, kiekviena civilizacija kuria unikalų meno stilių, kuris yra patikimas kitų civilizacijos aspektų pažinimo kriterijus ${ }^{23}$. Remiantis nurodytais kriterijai, būtų galima apibrèžti esminius civilizacijos požymius (jos identitetą). Civilizacijos sampratos esmę išreiškia kultūrinių tradicijų ir moralinių nuostatų visuma, nes civilizacija - tai ,šiuolaikinė išsivysčiusių pasaulio šalių kultūra“"24, o religija laikoma ,pačiu svarbiau-

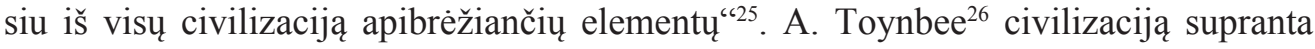
kaip patvarią žmonių bendriją, suvienytą visų pirma dvasinių tradicijū bei geografinių ribų. Civilizacijos sampratai apibrèžti yra reikšminga ir žmonių socialinė praktika bei ją išreiškiantys ekonominiai institutai. Neatsitiktinai mokslinėje literatūroje civilizacijos terminu apibrėžiamos panašius požymius turinčios politinės-teisinès sistemos, kurioms tirti paprastai taikomi du metodai: ,pirmuoju atveju dèmesi labiau kreipiant i simbolius, vertybes ir ideologines sistemas nei į socialinę praktiką, labiau į religiją ir

21 Spengler, O. Vakarų saulèlydis. Kultūra ir civilizacija. Vilnius: Lietuvos rašytojų sajungos leidykla, 1999.

22 Donskis, L. Kuo skiriasi lyginamųų civilizacinių studijų klasikai ir jų dabartinè banga. Baltos lankos. 1995, 6: 18-61; Pavilionis, Ž. Europos integracija ir civilizacijų susidūrimas, Politologija, supra note 13, p. 18-61; Andrijauskas, A. Metacivilizacinès kultūros metamorfozès ir globalizacijos prieštaravimai. Logos. Religijos, filosofijos ir meno žurnalas, supra note 13, p. 16.

23 Kultūros ir civilizacijos analizė [intersktyus]. [žiūrèta 2013-07-27]. <http://www.mokslai.lt/referatai/kursinis/1788.html>.

24 Tarptautiniu žodžių žodynas. Sudarytoja V. Vaitkevičiūtė. Vilnius: Vyriausioji enciklopedijų redakcija, 2004.

25 Tiriakian, E. A. Reflekctions on the Sociology of Civilizations. Sociological Analysis. 1974, 35.

26 Toynbee, A. A. Study of History / Abridgment of vol. I-VI by D. C. Somervell. New York: Oxford University Press, 1957. 
mitus nei ị ekonomiką; antruoju - atvirkščiai“"27. Taigi, yra pagrindo teigti, kad civilizacijos samprata apima visuomeninio elgesio normas, dvasines vertybes, tam tikrą kultūros stilių ir technologijos laimèjimus ${ }^{28}$. Prielaidos civilizacijų skirtumams atsirasti glūdi kultūrinių ir socialinių vertybių struktūroje.

Mokslinèje literatūroje paprastai skiriamos Vakarų ir kitos civilizacijos. I Vakaru civilizaciją žvelgiama kaip ì pažangią visuomenès organizavimosi formą (taip mano, pvz., A. Toynbi, S. Hantingtonas ${ }^{29}$ ), kadangi ją reprezentuoja aukštą išsivystymo lygi pasiekusi Vakarų Europos pilietinè bendruomenè, kuri paprastai yra priešinama neorganizuotai, nestruktūruotai Rytų visuomenei. Tuo tarpu kiti sociologai (pvz., S. Kirdina, V. Iljin, M. Romanenko ${ }^{30}$ ) Vakaru ir Rytuc civilizacijas pateikia kaip dvi visuomenès vystymosi alternatyvas, nes, anot jų, visuomenės organizacijos modeliai ,nèra veikiami laikmečio technologinės pažangos pokyčių ir išsaugo fundamentalias socialines Vaka$r u$ ir Rytu civilizacijų ypatybes ${ }^{6631}$, nors ir pripažistama, kad išorinis poveikis bet kurios sistemos funkcionavimui yra neišvengiamas: „,kiek bebūtų reikšmingos ekonominè ir politinè sritys civilizuotoje visuomenejje, jos anaiptol neaprèpia visų visuomenès veiklos sričių ${ }^{632}$.

Civilizacijų išskyrimą lemia pažiūrų i visuomenès organizaciją ir jos funkcionavimo principus skirtumai. Dèl civilizacijų įtakos susiklosto ne tik savitos kultūrinès tradicijos ir religinių pažiūrų sistema, bet ir ekonominiai, politiniai bei teisiniai žmonių tarpusavio santykiai. Minėtų požymių visuma ir leidžia kiek įmanoma tiksliau apibūdinti civilizacijos sampratą, atskleidžiant pagrindines jos reikšmes, kartu pabrèžiant ir civilizacijų esminius skirtumus. Tradicinè (Rytų) visuomenès santvarka grindžiama instituciniu valstybès sinkretizmu (kildintinu iš vietos bendruomenių sinkretizmo (susijungimo, bendruomenių sajungos), valdžios ir nuosavybės institutų joje suliejimu ${ }^{33}$, visų visuomeninio gyvenimo sričių monolitu, kur (ypač ankstyvaisiais viduramžiais) visiškai tarpusavyje susipina teisiniai, religiniai, politiniai, ekonominiai, šeimos ir kitokie visuomenès institutai. Tuo tarpu Vakaru civilizacija, kaip liberalizmo ir krikščioniškos socialinès filosofijos doktrinomis grindžiama autonominių struktūrų pagrindu funkcionuojanti visuomenès organizacija, yra paremta teisès, asmens laisvès ir rinkos

27 Terin, D. F. "Zapad” $i$ "Vostok” v institucionalnom podkhode k civilizacii ["West" and "East" institutional approach to civilisation]. [interaktyvus]. 2001 [žiūrèta 2010-07-02]. <http://www.nir.ru/Socio/-scipubl/sj/ sj4-01ter.html>.

28 Kultūros ir civilizacijos analizè, supra note 23.

29 Toynbee, A. A., supra note 26; Huntington, S. P., supra note 7.

30 Romanenko, L. M. Socialnye tekhnologii razreshenija konfliktov grazhdanskogo obshhestva: Ekhzistencialnye alternativy sovremennoj Rossii na poroge tretego tysjacheletija [Social technologies in civil community conflict resolution: Existential alternatives in contemporary Russia on the brink of the third millennium]. Moskva: Centr konfliktologii In-ta sociologii RAN, 1998; Ilin, V. V.; Akhiezer, A. Rossijskaja civilizacija: Soderzhanie, granicy, vozmozhnosti [A. Akhiezer. Russian civilization: Content, boundaries, possibilities]. Moskva: Izd-tvo MGU, 2000; Kirdina, S. G., supra note 8.

31 Terin, D. F., supra note 27.

32 Ibid.

33 Akhiezer, A. C. Rossija: Kritika istoricheskogo opyta (sociokulturnaja dinamika Rossii) [Russia: Critique of the historical experience (Russia's sociocultural dynamics]. T. 2. Teorija i metodologija: Slovar. Novosibirsk: Sibirskij khronograf, 1998, p. 509. 
(mainų) viešpatavimu ${ }^{34}$. Vakaru visuomenès organizacijai būdinga ,rinkos ekonomika, federaciné - subsidiari politiné santvarka, subsidiari ideologija“35, teikianti prioritetą individui kolektyvo atžvilgiu ${ }^{36}$, Rytu visuomenei - planinė ekonomika, unitarinè valstybės sandara, valdžios galios sutelkimas aukščiausioje valstybės valdymo grandyje, kolektyvinè ideologija, prioritetą teikianti bendriems visuomenès poreikiams ${ }^{37}$. Vaka$r u$ visuomenès socialinis susitvarkymas atspindi subsidiarumo idëjomis grindžiamus visuomenès santykius ir institucinius socialinių struktūrų ryšius, todėl subsidiarumas yra laikomas pamatiniu šią bendruomenę organizuojančiu principu, užtikrinančiu ją sudarančių socialinių struktūrų autonomiškumą, horizontalius subjektų ryšius, asmens veikimo laisvę ir jo poreikių preferencijas kolektyvinio intereso atžvilgiu. Rytu visuomenès socialinè santvarka remiasi subsidiarumui priešingais teisès institutais - unitarizmu (valstybės teritorijos vieningumu, nedalomumu), absoliučia valdžios galios koncentracija (valdžios sutelkimu aukščiausioje socialinės bendruomenès valdymo grandyje), komunitarine (kolektyvinių poreikių dominavimo) ideologija. Visa vakarietiška socialinès struktūros organizacija remiasi instituciniu subsidiarumu - visuomenès sutartimi, savivalda, korporaciniais bendruomenès narių ir instituciniais struktūrų ryšiais. Tuo tarpu Rytų visuomenės hierarchinis socialinių struktūrų funkcionavimas yra paremtas centralizuotu valdymu ir vertikaliais pavaldumo ryšiais, asmens iniciatyvų stoka ir kolektyvinių prioritetų visuomenèje dominavimu. Rytu ir Vakarų sistemas identifikuojantys institutai brèžia aiškią takoskyrą tarp Rytu ir Vakaru civilizacijose besiformuojančios socialinès tvarkos ir teisinių visuomenès santykių, pirmuoju atveju grindžiamų centralizuotu valdymu, centrinès valdžios paliepimų ir nurodymų vykdymu (,valdymu iš viršaus“), antruoju - bendruomenès sutartimi (chartijomis) ir korporaciniais visuomenès narių tarpusavio santykiais, horizontaliais socialinių struktūrų ryšiais (iniciatyvų kèlimu , ,iš apačios $\left.{ }^{6}\right)^{38}$. Subsidiarumo principas kaip socialinių sistemų institucionalizavimo instrumentas padeda atskleisti esminius visuomenès organizacijų teisinių santykių ir socialinių struktūrų sąrangos skirtumus, Vakarų visuomenėse paremtus vertybinèmis nuostatomis (tokiomis kaip teisinè sąmonè, teisès tradicija) ir socialine žmonių praktika, Rytų visuomenèse - išimtinai politiniais ir ekonominiais institutais bei iš jų kylančiomis ideologijų preferencijomis.

\section{Subsidiarumo principo įtaka politinių-teisinių sistemų funkcionavimui}

Subsidiarumo principas (kildintinas iš Vakaru visuomenès) yra tas teisinio reguliavimo instrumentas, kuriuo socialinejje bendruomenèje institucionalizuojamos visuomenès vertybinès nuostatos ir socialinès būties poreikiai. Kokia gi reikšmè tenka subsi-

\footnotetext{
34 Akhiezer, A. C., supra note 33, p. 130.

35 Kirdina S., supra note 8.

36 Ibid.

37 Ibid.

38 Kondratienè, V., supra note 16, p. 77.
} 
diarumui institucionalizuojant valstybès organizaciją kaip politinị ir teisinị visuomenės darinị.

Valstybès sandara lemia vidinị valstybès teritorijos padalinimą, teisinị valstybès teritorinių subjektų statusą, centrinès ir vietos valdžios santykių struktūrą. Valstybès teritoriniam suskirstymui turi įtakos gamtinès-geografinès sąlygos, etninė gyventojų sudėtis, istorinès tradicijos, kultūriniai savitumai ir socialiniai-ekonominiai veiksniai. Mokslinèje literatūroje skiriamos šios pagrindinès valstybių sandaros formos - unitarinè (vieninga, suvienyta), kurios „,sudètinès dalys neturi politinio savarankiškumo“39 ir federacinė (sudètinè, jungtinė), ,susidedanti iš kelių valstybinių darinių, turinčių ypatingą politinị teisinị statusą “40. Federacija reiškia, kad kelios valstybės ar žemesnio lygio nacionaliniai dariniai arba istoriškai susiklostę teritoriniai junginiai yra susivieniję i vieną valstybę. Valstybès, įeinančios ị federaciją, federalinei valdžiai perduoda tik dalị savo suverenių teisių. Tuo federacija skiriasi nuo unitarinès valstybès, sutelkusios centre visą suverenitetą. Teoriškai negalima nustatyti, kiek valstybingumo turi likti į federaciją susijungusioms valstybėms ir nacionaliniams dariniams, kiek jo reikia perduoti naujai valstybei - tai lemia visuomenès reikmès, socialinių jègų santykis. Dvilypiame valstybingume slypi federalizmo pavojai - jei centro ir ,pakraščių“ interesai nesutampa, pirmasis federacijos raidą kreipia unitarizmo, o antrieji - konfederacijos linkme ${ }^{41}$. Kitokie valstybių susivienijimai, kai susijungia dvi ar daugiau suverenių valstybių, vadinami konfederacija (valstybių sajunga, unija, bendrija ir pan.). Taigi „šiuolaikiniame pasaulyje taikiai (o kai kada, deja, ir netaikiai) sanbūviauja unitarinès valstybès, federacijos ir konfederacijos ${ }^{642}$. Pagrindiniais konfederacijos, federacijos ir unitarinès valstybės skirtumais derètų laikyti disponavimo valdžios galia principus. Subsidiarumo principo taikymo koncepcija šiose valstybių organizacijose skiriasi tuo, kad konfederacijoje jis padeda išlaikyti ją sudarančių valstybių narių disponavimo valdžios galia prioritetą konfederacijos centrinių institucijų atžvilgiu, federacijoje - subalansuoja federalinès valdžios ir federacijos subjektų igaliojimus ir teisinę jų padètį, unitarinèje valstybèje - jis padeda sumažinti centrinès valdžios galios koncentraciją, dali jos perkeliant ị žemesnị valdymo lygị. Taigi subsidiarumas yra veiksmingas valdymo galių balansavimo instrumentas, padedantis išvengti per didelès galios koncentracijos bet kurioje socialineje organizacijoje ir bet kuriame valdžios galia disponuojančiame institute. Subsidiarumo principo paskirtis - įtvirtinti konstitucinę socialinio darinio sandaros formą atitinkantị valdžios galių paskirstymą ji sudarantiems subjektams.

Konfederacija dažniau traktuojama kaip valstybių sajunga nei kaip valstybės organizacijos forma, todèl valstybių - konfederacijos narių, santykių tyrimas yra priski-

39 Baglaj, M. V.; Lejbo, Ju. I.; Ehntin, L. M. Konstitucionnoe pravo zarybezhnykh stran [Constitutional law in foreign countries]. Moskva: NORMA, 2004, p. 153.

40 Ibid.

41 Gaižiūnas, J. Nacijos tapsmas: lietuvių tauta istorijos ir dabarties kryžkelèse. Vilnius: Periodikos,1990, p. $49-50$.

42 Rinkos ūkio pasaulyje yra trys politinès ir ekonominès galios regionai (centrai): Japonija, kuri yra unitarine valstybė (kaip ir nuo jos neatsiliekanti, pagal atskirus ekonominius rodiklius ir ją lenkianti Kinija $-V$. K. pastaba), JAV - federacinė valstybè, ES - valstybių konfederacija. Ibid., p. 45. 
riamas tarptautinès teisès sričiai, o konfederacija laikoma tarptautinès teisès subjektu. Subsidiarumo principas padeda įtvirtinti konfederacijos narių disponavimo valdymo galia teisių prioritetą jų sudarytos centrinės administracijos atžvilgiu. Derètų pasakyti ir tai, kad mokslinèje literatūroje kartais tarp federacijos ir konfederacijos dedamas lygybės ženklas (Šveicarija to pavyzdys, ji pradèta kurti dar $1291 \mathrm{~m}$. ir iki XIX a. vidurio buvo konfederacija ${ }^{43}$, vèliau peraugo i federaciją). Jei socialiniame darinyje valdymo galia priklauso sajungos subjektams (valstybėms, kitiems konfederaciją sudariusiems nacionaliniams teritoriniams junginiams, kurie valdžios galią (ar jos dalị) perduoda (deleguoja) jų sudarytai centrinei administracijai, tokia organizacija laikytina konfederacija (valstybių, kitų politinių teritorinių junginių sajunga). Jei valdymo galia kyla iš centrinès valdžios, kuri dali jos perduoda administraciniams teritoriniams vienetams, tuomet derètų kalbėti apie unitarinị darinị (vieningos valstybės organizaciją). Tuo atveju, kai valdžia yra padalinta tarp federalinès valdžios ir federacijos subjektų, o išimtinės kompetencijos turinys (dèl teisinès subjektų padèties) iš anksto yra nulemtas (kylantis iš prigimtinès federacijos subjektų teisès), tokị valstybės darinị derètų laikyti federacija (suvienyta valstybe).

Konfederacijoje valdžios galios šaltinis (bendroji kompetencija) yra valdomas valstybių narių. Kiekvienas jos narys yra suverenus ir turi didelę veiksmų laisvę vidaus ir užsienio politikoje. Konfederacijos narių centrinei valdžiai suteikta kompetencija yra išvestinè, todèl jos veikimas yra visiškai priklausomas nuo valstybių - konfederacijos narių. Centrinės administracijos igaliojimai yra įtvirtinti konfederacijos sutartyje. Konfederacijų susivienijimo pobūdis yra skirtingas, nuo formalaus (silpni organizaciniai valstybių narių ryšiai) iki itin glaudaus (kai kuriami bendri konfederacijos organai, pavyzdžiui, Europos Sajungos). M. Romeris konfederaciniams susivienijimams priskiria „vadinamąsias administracines unijas (sui generis konfederacija), ịvairaus pobūdžio sajungas. Savotiška konfederacijos forma - personalinè unija (kai vienas asmuo yra dviejų atskirų valstybių vadovas, pavyzdžiui, Lenkijos ir Lietuvos) arba realinè unija (pavyzdys - Austrijos-Vengrijos iki Pirmojo pasaulinio karo) ${ }^{\text {‘44 }}$. Taigi, konfederacija nepriskirtina valstybių sandaros formai ir laikytina tarptautiniu teisès subjektu, todèl bet kurių valstybinị statusą turinčių subjektų susijungimas tam tikriems bendriems klausimams (tarptautiniams, gynybos ir pan.) spręsti (pvz., JAV ir Vokietija pradiniame jų susivienijimo etape) laikytinas konfederacija. Ir nors iki šiol, pavyzdžiui, dèl Europos Sajungos organizacinio modelio yra diskutuojama - Europos Sajunga pagal skirtingą jos sąrangos suvokimą laikoma konfederacijos (valstybių sajungos) ir federacinès (sajunginės, suvienytos) valstybės požymių turinčia organizacija ${ }^{45}$, vis dėlto, pavyzdžiui, J. Gaižiūnas mano, kad ES atitinka konfederacijos požymius. Susivienijimas įteisintas sutartimi; jis nėra valstybè, o valstybių sajunga ${ }^{46}$, nes ,konfederacija

43 Gaižiūnas, J., supra note 41, p. 46.

44 Romeris, M. Unitariné valstybe ir valstybiniai junginiai. Vilnius: Justitia, 2008, pabaiga - p. XXI.

45 Nef, R. Da zdravstvuet noncentralizm! [Long live non-centralism!]. Per.s. nem. / Robert Nef; Friedrich Naumann Stiftung. Moskva: MAKS-press: Fond F. Naumanna, 2002 [interaktyvus]. [žiūrèta 2011-02-21]. $<$ www.libinst.ch/publikationen/LI-Nef-Non-Zentralismus-ru.pdf>. 
reikalinga ir efektyvi ten, kur įvairias nacijas atstovaujančios valstybès, kurios viena nuo kitos skiriasi nacionaliniais ypatumais, dažniausiai ir ekonominès, socialinès bei kultūrinès raidos lygiais ${ }^{647}$. Kartu galima pasakyti, kad Europos Parlamento įsteigimas ir jo sudarymo principai leidžia manyti, kad ES piliečių (ar mažiausių nacionalinių vietos bendruomenių) interesai gali pasiekti aukščiausias ES valdymo institucijas, jei šiems interesams bus tinkamai atstovaujama. Akivaizdu ir tai, kad ši valstybių Sajunga stovi ,ant federacijos slenksčio“"48, sudarydama „tarptautinèje bendruomenèje specifini ansamblị ‘49, kurio tolesnè plètra tiesiogiai priklauso nuo Europos bendruomenès pasirinkimo - taikyti ar atmesti principinę subsidiarumo sampratą - pagrindinius valdžios svertus patikèti vietos bendruomenès interesams atstovaujančiai valdžiai, ar ir toliau galios pusiausvyros centrą stumti nuo nacionalinès valdžios Bendrijos institucijų link ${ }^{50}$.

\subsection{Subsidiarumo principo institucionalizavimas valstybès valdyme}

Subsidiarumo principo institucionalizavimas valstybès valdyme - tai igaliojimų skirtingo lygmens institucijoms paskirstymas, leidžiantis pasiekti sprendimų poveikio atitikties problemų mastui pusiausvyrą, kitaip tariant, užtikrinti priimamų sprendimų maksimalų veiksmingumą visose valstybės valdymo grandyse. Šiuolaikinėse valdymo sistemose šis principas yra laikomas veiksmingu instrumentu sprendimams žemesniame nei valstybinis, bet aukštesniame nei vietinis valdymo lygmuo priimti, tuo sukuriant realias prielaidas regioninei dimensijai valstybès teritorinėje - administracinèje sistemoje įtvirtinti. Regioninio lygmens valstybès valdymo sistemoje institucionalizavimas grindžiamas tolygios (subalansuotos) krašto teritorinès plètros poreikiu bei regioną atitinkančios politikos ịgyvendinimu.

Europos Sajunga skiria išskirtinị dėmesị regioninei politikai, padedančiai pasiekti sprendimų veiksmingumą visose valstybès valdymo grandyse, nes ,efektyvus valstybès valdymas sukuria realias prielaidas tolygiai visos valstybės ir konkrečiu jos teritorinių darinių socialinei ir ekonominei raidai“"51. Ir nors Europos Sajunga tiesiogiai nesikiša į valstybių - narių teritorijų regionalizavimo klausimus, tačiau aktyviai remia pastangas išsaugoti Europos identitetą - kultūrų ir regionų įvairovę (tai ịtvirtinta ES sutarties preambulëje, 126 str., 128 str. ir kt. str. ${ }^{52}$ ). Europos Bendrija prisideda prie valstybių narių kultūrų klestėjimo, taip pat gerbia jų tautinę ir regioninę įvairovę, kartu iškeldama bendrą kultūros paveldą ${ }^{53}$. ES sutartyje įtvirtintos nuostatos laikytinos pagrindinėmis nacionalinių valstybių politikos gairèmis, kurių igyvendinimui turètų

47 Gaižiūnas, J., supra note 41, p. 46.

48 Chagnollaund, D. Droit contemporain. tome 1, 4e edition, Paris: Armmand Colin, 2005, p. 127.

49 Ibid., p. 127.

50 Cairns, W. Europos Sajungos teisès juvadas. Vilnius: Eugrimas, 1999, p. 138.

51 Kondratienè, V. Lietuvos valstybès regioninè politika ir valstybès valdymas atsižvelgiant ị Europos patirtị. Justitia. 2003, 6 (48): 52.

52 Europos Sajungos sutarties ir Sutarties dėl Europos Sajungos veikimo suvestinès redakcijos [intersktyus]. [žiūrèta 2013-07-27]. <http://eur-lex.europa.eu/LexUriServ/LexUriServ.do?uri=OJ:C:2010:083:FULL:LT :PDF>.

53 Europos Sajunga: steigimo dokumentu rinktinè. Vilnius: Eugrimas, 1998, p. 251. 
būti skiriama ypatinga reikšmė. Pastangos išsaugoti savitumu pasižyminčius Europos regionus - tai pačios Europos identiteto išsaugojimas bei bandymas globalioje erdvèje išlaikyti pusiausvyrą tarp kultūrų niveliavimo ir tautinio identiteto apsaugos. Šiam balansui įtvirtinti Europos Sajungoje pasitelktas subsidiarumo principas, reikalauja išsaugoti kultūrų bei regionų ịvairovę ir globalioje erdvèje nenustelbti savitumu pasižyminčių darinių. Jis kaip visumą integruojanti priemonè harmonizuoja dalies santykị su visuma, padėdamas išsaugoti ịvairovę vienovèje. Subsidiarumo principo koncepcijos pasirinkimas regioniniam lygmeniui valstybės valdymo sistemoje institucionalizuoti ir subjektų igaliojimams šiame valdymo lygmenyje paskirstyti tiesiogiai priklauso nuo teisinès aplinkos - šalies konstitucijoje ir /ar įstatyme įtvirtintos valstybès sandaros formos, teritorinès administracinių vienetų sistemos. Vadinasi, nacionalinè teisé yra tas pagrindas, kuriuo remiantis valstybès organizacijoje institucionalizuojamas regioninis valdymo lygmuo ir teritorinė savivalda, kuriama ir igyvendinama nacionalinè regioninė politika visos valstybės mastu. Lietuvoje kaip vienoje iš ES narių regioninès politika turi būti grindžiama EB teisejje įtvirtintais - federalizmo, subsidiarumo, valdymo sistemos demokratizavimo, decentralizavimo, savivaldos ir kt. principais, kuriais remiantis gali būti determinuota centralizuota Lietuvos kaip unitarinès valstybės valdymo sistema, joje išskiriant ir regioninị lygmeni sprendimų veiksmingumui visose valdymo grandyse pasiekti.

Europos komiteto prie LR Vyriausybès išleistame leidinyje „Europos lèšos ir patirtis - šansas kiekvienam regionui“ rašoma, kad Europos valstybių valdymas skiriasi ir yra pritaikytas konkrečioms šalies sąlygoms. Liuksemburgas, turintis apie 400 tūkst. gyventojų, suskirstytas ị tris sritis, kuriose centrinei valdžiai atstovauja jos skiriami valdytojai. Portugalijoje $(9,83 \mathrm{mln}$. gyventojų) ilgą laiką, be nacionalinès valdžios, buvo per 300 savivaldybių. Prieš keletą metų šioje šalyje ịvesta tarpiné grandis - administraciniai regionai, kurių vidutinis dydis yra apie $2 \mathrm{mln}$. gyventojų. Airija (3,5 mln. gyventojų) suskirstyta ị 29 savivaldą turinčias grafystes, tačiau joje, kaip ir daugelyje kitų Vakarų ir Šiaurès Europos šalių, yra įprasta konkretiems tikslams sudaryti administracines struktūras, apimančias keletą savivaldybių. Tokio principo bus laikomasi ir nuo ateinančių (2001 m. - aut. past.) metų, kai Airija Europos Sajungoje bus laikoma dviejų regionų junginiu. Daugiau nei $5 \mathrm{mln}$. gyventojų turinti Danija suskirstyta ị 14 regionų, kurių vidutinis dydis beveik toks pats kaip Lietuvos apskričių. Savivaldybių Danijoje šiuo metu yra 275. Vidutiniškai jos beveik keturis kartus mažesnès nei Lietuvoje, todèl danų savivaldybių santykiai su aukštesniais valdymo vienetais kiek kitokie nei mūsų šalyje ${ }^{54}$. Pateikta Europos valstybių regionalizavimo praktika liudija, kad kiekviena valstybe kuria savitomis krašto tradicijomis ir bendruomenès poreikiais grindžiamus regionų modelius, todèl jie yra gyvybingi atitinkamos šalies politiniame, ūkiniame bei kultūriniame gyvenime.

Kiek kitokia yra Lietuvos valstybès patirtis. Visą atkurtos Lietuvos nepriklausomybės laikotarpị nei savivaldūs (autonominị ar administracinị statusą turintys), nei funkciniai (funkciniams regionams iš dalies gal ir galima prilyginti laisvas ekonomines zonas, 
įsteigtas Vilniuje, Kaune, Šiauliuose), nei etnografiniai (atitinkantys ES sutarties 128 straipsnyje įtvirtintą kultūrų ir regionų ịvairovès sampratą ${ }^{55}$ ) regionai Lietuvoje taip ir nebuvo sukurti, nors apie tai pradèta kalbèti dar 1993-1994 m. prieš steigiant apskritis. Gaila, kad tik po septyniolikos nepriklausomos Lietuvos valstybės metų suvokta, kad regionas nèra tik administracinis vienetas valdymo galiai paskirstyti, bet jo teritorijai išskirti svarbi ir istorinè-etnokultūrinè savastis, todèl nuo $2010 \mathrm{~m}$. galiojančios Lietuvos Respublikos teritorijos administracinių vienetų ir jų ribų ịstatymo redakcijos 2 straipsnio 2 dalies antroje pastraipoje pagaliau įtvirtinta regiono identitetui reikšminga nuostata: „Apskritis sudaroma iš savivaldybių teritorijų, pasižyminčių socialinių, ekonominių ir etnokultūrinių interesų bendrumu“"56. Taigi, pagaliau suvokta, kad teritorinis interesų bendrumas yra reikšmingas kriterijus teritorinei-administracinei sistemai formuoti ir pagrindinis veiksnys tolygiai (subalansuotai) regioninei plètrai užtikrinti. Ši minèto ịstatymo nuostata leidžia tikètis, kad valstybès valdžiai nepritrūks išminties kuriant naujus regionus pasiremti ir moksliniais tyrimais, kuriuose yra nurodomi pagrindiniai regionų formavimo principai ${ }^{57}$.

\section{Subsidiarumo principas kaip Europos bendruomenę vienijanti idèja}

Subsidiarumas pagrịstai laikomas universaliu procesų, sistemų ir santykių reguliavimo instrumentu. Vadovaujantis šiuo fundamentaliu integracijos principu buvo ịsteigta Europos Sajunga, kurios atsiradimas paskatino valstybių teritorijų atvirumą, modernių visuomenès plètros koncepcijų, regionų, ekonominès veiklos bei socialinès infrastruktūros centrų kūrimą. Sparti teisinių ir ekonominių sistemų integracija leido naujai ịvertinti vieningos organizacijos galimybes sprendžiant Europos Bendrijos piliečių socialines-ekonomines problemas, ir pasirinkti savitą Europos socialinị modelį, kuriame „socialiai orientuota rinkos ekonomika“ kaip „kapitalo ir darbo priešpriešos

55 Europos Sajunga: steigimo dokumentu rinktiné, supra note 53, p. 251.

56 Lietuvos Respublikos teritorijos administracinių vienetų ir jų ribų įstatymas. Valstybés žinios. 1994, Nr. 60-1183; 2004, Nr. 135-4893; 2010, Nr. 41-1934.

57 Lietuvai „naujoje europinèje erdvèje valstybès identitetui ir tautos etniniam mentalitetui išsaugoti būtini savitumu pasižymintys regionai, kuriuose valdymą organizuoja centrinès valdžios ịgaliota institucija arba regiono bendruomenės išrinkta valdžia. Bendruomenė yra šių regionų gyvybingumo pradas, o regioninis savitumas pasireiškia konkrečioje teritorijoje gyvenančios bendruomenès istorijos eigoje susiformavusių etnokultūrinių, socialinių ir ekonominių interesų bendrumu. Būtent tai ir sudaro teisines prielaidas tam tikrai teritorijai išskirti. Toks teritorijos išskyrimas, suteikiant vietos bendruomenei teisę per jos išrinktą valdžią organizuoti valdymą regione, būtų reikšmingas ir visokeriopai skatintinas. Tačiau savivaldos įtvirtinimas regione, kurio bendruomenè neturi bendros (vienijančios $-V . K$. pastaba) etninès savimonès ir kultūrinès savasties, kuris sukurtas dirbtinai, t. y. apskričių (neturinčių teritorijos istorinio savitumo $V . K$. pastaba) sudarymo principu, arba regionas, kuriame dominuoja tik ekonominiai, bet ne nacionaliniai valstybės ir tautos interesai, gali sukelti grèsmę Lietuvos teritorijos vientisumui. “ Kondratienė, V. Lietuvos regioninė politika Europos patirties kontekste. Lietuvos regioniné politika ir teritorinés sandaros tobulinimo problema. $2004 \mathrm{~m}$. balandžio 14 d. konferencijos medžiaga. Vilnius: Mykolo Romerio universitetas, 2004, p. 36. 
ịveikos išraiška"“58 tapo Vakarų Europos valstybių socialine realybe, o daugelyje Rytų ir Vidurio Europos valstybių - socialine siekiamybe, reikalaujančia ne tik ekonominès sistemos pertvarkymų, bet ir visuomenès teisinès sąmonès pokyčių. Todėl valstybių ir jos vyriausybių strateginiu tikslu tapo - sukurti tokią ekonominę politiką, kuri sumažintų visuomenès problemas, padidintų gaunamą naudą ${ }^{59}$ ir užtikrintų socialinę gerovę visiems. Taigi, Europos Sajunga pasiryžo sukurti tokị valstybių bendravimo ir bendradarbiavimo modelį, kuris leistų, plètojant socialinès teisinès valstybès koncepciją, suderinti Vakarų Europos ir Rytų bei Vidurio Europos valstybių teisinių bei ekonominių sistemų organizavimo skirtumus. Europa pirmoji atkreipè dèmesị ị subsidiarumo kaip tiesioginę socialinę paskirtị turinčio teisès principo reikšmę socialinès teisinès valstybès modeliui igyvendinti, nes juo galima subalansuoti viešojo ir privataus sektoriaus igaliojimų turinį, nustatyti aiškias valstybės dalyvavimo rinkoje ribas bei poveikio ekonomikai priemones kuriant socialiai orientuotos rinkos modeli. Remiantis juo, valstybės organizacijoje individualizuojami visuomenès narių poreikiai bei palaikomos asmens iniciatyvos, ịtvirtinami savitarpio pagalbos ir paramos savimi negalintiems pasirūpinti asmenims principai. Subsidiarumas tiesiogiai tarnauja visuomenès siekiams ir yra šios visuomenès teisinès sąmonès ir jos socialinio susitvarkymo atitikmuo. Jo paskirtis ekonominių sistemų reguliavime - realizuoti visuomenès vertybines nuostatas atitinkanti išteklių ir viešujų gèrybių paskirstymą pagal jos nustatytą prioritetų hierarchiją, kuriai igyvendinti būtini atitinkami socialiniai-ekonominiai institutai.

Subsidiarumo idejjos populiarumas Europoje grindžiamas tuo, kad „subsidiarumas iškyla kaip politinè ir humanistinè idejja, etinè ir socialinè vertybè, turinti ilgametę Europos politinès minties tradiciją “60, kuria remiantis kiekviena socialinė bendruomené yra pajègi išspręsti kylančias problemas, ịveikti nesutarimus ir pasiekti interesų pusiausvyrą. Subsidiarumo giluminès prasmès ir vertybinès reikšmès socialiniam visuomenès susitvarkymui suvokimas pastūmėjo Europos valstybių bendruomenes pasiremti subsidiarumo idejja didejjančio nacionalinio susipriešinimo Europoje laikmečiu (XX m. pradžia, taip pat laikotarpis po Antrojo pasaulinio karo) ir kurti Europos saugumą ir taikų žmonių bendrabūvị skatinančias struktūras. Neatsitiktinai subsidiarumas kaip harmoningos socialinès tvarkos idejja (interesų derinimo, jų pusiausvyros įtvirtinimo visuomeneje ir sprendimų žemiausioje valdymo grandyje priemimo mechanizmas) tapo bene vienintele priemone jautriam nacionalinio suvereniteto ribojimo klausimui Europos valstybių bendrijoje spręsti, šio ribojimo tikslą suprantant kaip didesnio nacionalinio ir bendrojo Europos saugumo užtikrinimo galimybę. Subsidiarume - Europos

58 Merkel, A., supra note 14, p. 43.

59 Efektyvus vyriausybės vaidmuo sprendžiant ekonomikos problemas pasireiškia tuo, kai: (1) iki minimumo mažinamas nedarbo lygis; (2) stabilizuojamos kainos; (3) didinamas ekonominis efektyvumas; (4) teisingiau paskirstomos pajamos; (5) užtikrinamas spartesnis ekonominis augimas ir kt.

60 Bolshakov, S. N. Princip subsidiarnosti v sovremennom demokraticheskom upravlenii: konceptualnye podchody i problemy prakticheskoj realizacii [The principle of subsidiarity in modern democratic management: conceptual approaches and problems of practical implementation]. Dis. D-ra polit. nauk. 2006, $372 \mathrm{~s}$. RGB OD, 71:07-23/15, 2006 [interactive]. [accessed 2012-10-18]. <www.lib.ua-ru.net/diss/cont/188411. html $>$. 
vertybes vienijančioje doktrinoje, Europos bendruomenè pagaliau atrado nacionaliniu konfliktų sprendimų galimybę ${ }^{61}$. Subsidiarumas kaip lankstus interesų derinimo instrumentas sudare realias prielaidas suvienyti Europą ir 1986 m. Liuksenburge ir Hagoje paskelbti Suvestini Europos aktą, o 1992 m. Mastrichte pasirašyti ir Europos Sajungos steigimo sutarti, kurių tikslas - sustiprinti Europos valstybių bendradarbiavimą itin visuomenei jautriose tarptautinio saugumo, užsienio politikos, žmogaus teisių ir pagrindinių laisvių apsaugos srityse, konsensuso būdu sprendžiant visai pasaulio bendruomenei svarbius išorinio saugumo ir politinio bendradarbiavimo klausimus.

Absoliuti dauguma mokslininkų mano, kad Europos Bendrijų istorijoje pirmą kartą subsidiarumo principu Komisija pasinaudojo 1975 m. - savo išvadoje apie Europos Sajungos projektą teige „Europos Sajunga netaps supervalstybe, nes spręs tik tuos klausimus, kurių išspręsti negalès valstybès narès" ${ }^{\text {"62 }}$. Subsidiarumo principu Komisija grindė $\mathrm{EB}$ ir nacionalinių valstybių kompetencijos atribojimą, Bendrijai priskiriant tik tuos klausimus, kurių nepajègia išspręsti valstybès narès. Jau nuo XX m. aštuntojo dešimtmečio subsidiarumo principu nuolat vadovaujamasi diskusijose dèl ES steigimo ir jis įtraukiamas ị Europos socialinès chartijos ${ }^{63}$ tekstą (kaip priemonè Bendrijos dirbančiųjų pagrindinèms teisèms ir socialinèms garantijoms užtikrinti) ir kitus EB dokumentus.

1980 m. A. Spinelli, žymus Europos federalistas, pasiūlè pasinaudoti subsidiarumo principu Europos valstybių integracijai paspartinti ịkuriant Europos valstybių federaciją, kurioje kiekviena valstybė nare išsaugotų autonomiją, būtiną tolesniam harmoningam šalies politinio gyvenimo vystymuisi atsižvelgiant ị kiekvienos tautos savitumą ${ }^{64}$ 1984 m. A. Spinelli vadovaujama grupé parengè ES sutarties projektą, kuriuo siekta subalansuoti EB institucijų galias - sustiprinti Europos Parlamento (toliau vadinama EP) vaidmeni, susiaurinant Europos Tarybos (toliau vadinama - ET) igaliojimus. Taip pat jame numatyta ribojant valstybių naių kompetencijas išplèsti Bendrijos ịgaliojimus ekonominès, monitarinės, socialinės politikos, kultūros ir tarptautinių santykių srityse, tikintis, kad Bendrijos veikimas šiose srityse būtų efektyvesnis nei sprendimų prièmimas nacionaliniu lygmeniu ${ }^{65}$. Projekto 12 (2) straipsnyje nurodomas kuriamos ES tikslas - Sajunga kuriama uždaviniams, kuriuos lengviau išspręsti kartu, iš dalies turint omenyje ir tas problemas, kurių sprendimas išeina už nacionalinių valstybių kompetencijų ribų ${ }^{66}$. A. Spinelli subsidiarumo principo naudą grindè tuo, kad juo vadovaujantis

61 Kaip teigia A. Merkel, „Europos tautų istorijai daug šimtmečių buvo būdingi dideli, milžiniški, baisūs konfliktai. Ne vieną šimtmetį jie kildavo dèl religinių motyvų... XX a. Europą ir pasaulį užliejo <...> nacionalinių konfliktų ir ideologiškai motyvuotų karų sukelta baisumų ir žudynių banga. Merkel, A., supra note 14 , p. 39.

62 Europos Sajunga: enciklopedinis žinynas. Vitkus, G. (sud.). Vilnius: Eugrimas, 2002, p. 295.

63 Europos socialinè chartija [interaktyvus]. [žiūrèta 2011-02-09]. <eur-lex.europa.eu/.../-C2007303LT. 01001701.htm>.

64 Spinelli, A.; Rossi, E. The Ventotene Manifesto. Reader on the History and Theory of the European Integration. Part I. Compiled by M. Larionova, State University Higher School of Economics, p. 150.

65 European Markets after 1992 / Ed. by Timothy M. Devinney, William C. Hightower. Lexington, Mass.: Lexington Books, 1991, p. 39.

66 Gomcjan, S. V. Dinamika razvitija principa subsidiarnosti v Evropejskom sojuze [Subsidiarity principle development dynamics in the European Union]. Vestnik mezhdunarodnykh organizacij. 2007: 6(14), p. 57. 
galima išvengti perdèm didelès centralizacijos ir viršnacionalinės vyriausybės steigimo bei subalansuoti federalizmo ir centralizmo šalininkų politinius interesus, nes priešingu atveju tolesnè ES integracija gali tapti neịmanoma. Ir nors EP pritarè parengtam ES projektui, tačiau jis taip ir liko tik projektu, tačiau subsidiarumo principas kaip ES ir valstybių narių igaliojimų igyvendinimo instrumentas, palaikant Ž. Delorui, buvo įtvirtintas ị Suvestinị Europos Aktą. Jame subsidiarumo principas reiškia išlygą, kad Bendrija, vykdydama aplinkosaugos politiką, veiksmų imsis tik tada, kai nacionalinių valstybių institucijos negalès jų atlikti geriau, o Bendrijos veiksmai bus efektyvesni nei tie, kurių imasi valstybès nacionaliniu lygmeniu. Šiuo dokumento 25 straipsniu subsidiarumo principas (kaip EB ir valstybių narių bendrojo veikimo aplinkosaugos srityje mechanizmas) buvo įtrauktas ị EEB sutarti.

Subsidiarumo principo įtvirtinimui ES teisèje yra reikšminga Mastrichto sutartis (apibrėžianti subsidiarumo principo sampratą, ES ir valstybių narių kompetencijas), Amsterdamo sutartis ir ypač jos Protokolai (nustatantys detalius subsidiarumo principo taikymo kriterijus ir procedūras, ES ir valstybių narių kompetencijų paskirstymo ir jų igyvendinimo principus), taip pat Nicos sutartis (sustiprinusi subsidiarumo principo kontrolès sistemą), Sutartis dèl Konstitucijos Europai, kurioje ịtvirtintos ES ir valstybių narių kompetencijų grupės, jų atribojimo ir realizavimo mechanizmai, vėliau tapo Lisabonos sutarties kertine ašimi kuriant vieningą subsidiarumo principo politinès ir teisminès kontrolès sistemą (sudariusią realias prielaidas nacionaliniams parlamentams dalyvauti ES teisèkūros ir subsidiarumo principo pažeidimo kontrolès procese). Teoriniam subsidiarumo principo sampratos suvokimui ir jo praktiniam taikymui ypač reikšmingi ET, EP ir Europos Ateities konvento dokumentai, taip pat Europos Teisingumo Teismo (toliau vadinama - ETT) teikiamas šio ir kitų (iš Europos Bendrijos sutarčių kildinamų) bendrujų Europos Bendrijos teisès principų aiškinimas ${ }^{67}$.

Europos Sajungos sutartis, pasirašyta $1992 \mathrm{~m}$. vasario $7 \mathrm{~d}$., Mastrichte (toliau vadinama - Mastrichto sutartimi) ${ }^{68}$ - pirmas ES teisès aktas, įtvirtinęs subsidiarumo principo sampratą ir sudaręs galimybę tolesniam jo taikymui ES ir nacionalinių valstybių teisejje. Itvirtinus subsidiarumo principą Mastrichto sutartyje, imtos svarstyti ir jo platesnio panaudojimo galimybès Europos Sajungos ir valstybių narių instituciniams santykiams reguliuoti (kompetencijoms atriboti ir galioms skirtingais valdymo lygmenimis nustatyti), tapusios šio principo tolesnès plètros ir jo institucionalizavimo Europos Bendrijos ir nacionalinių valstybių teisèje pagrindu. Remiantis subsidiarumo principu, iš vienos pusès, siekiama įtvirtinti reikalavimą sprendimus priimti arčiau ES piliečių, iš kitos - sudaryti teisines prielaidas ES imtis kompetencijos ribas peržengiančių veiksmų ES tikslams ịgyvendinti, jei valstybės narès nepajègia problemų išspręsti

67 Bendrieji Europos Bendrijos teisès principai aprèpia visas Bendrijos veiklos sferas ir tiksliai atskleidžia Bendrijos teisès ir valstybių narių nacionalinių teisių sistemų sąveiką. Jie susiformavo atsiradus būtinybei priimti sprendimus dèl dalykų, kurių aiškiai neaptarè Sutartys. Šie principai yra išplètoti iš Sutarčių bei sprendimo prièmimo metu valstybių narių teisinėse sistemose buvusių teisinès minties krypčių. Usher, J. A. Bendrieji Europos Bendrijos teisès principai. Vilnius: Naujoji Rosma, 2001, Vyriausiojo redaktoriaus ižăanga, p. 1.

68 Mastrichto sutartis [interaktyvus]. [žiūrèta 2011-01-12]. <http://ec.europa.eu/lietuva/abc_of_the_eu/-eu_ law/index_lt.htm>. 
jų kilimo vietoje ${ }^{69}$. Dèl šio nevienareikšmio (skirtingus interesus tenkinančio) subsidiarumo principo apibrèžimo ES sutarties projekto rengèjams pavyko ịtikinti centralizmo ir federalizmo šalininkus įtraukti subsidiarumo principo terminą į ES dokumentus ${ }^{70}$. Susitarti dèl subsidiarumo sampratos Europos Sajungos valstybėms pavyko tik todèl, kad ši sąvoka gali būti ịvairiai interpretuojama. Subsidiarumo principo sampratos kvintesencijai ES yra paskirtas išsamus L. Blicherio ir L. Sangolto tyrimas ${ }^{71}$, kuriame ne tik pateikiama subsidiarumo sampratos koncepcija, bet ir analizuojamos pliuralistinio požiūrio ị ši reiškinị priežastys. Subsidiarumo samprata nuodugniai ištirta ir šio straipsnio autorès disertacijoje „Subsidiarumo principas ir jo taikymas valstybès valdymui ir vietos savivaldai“'72. Iš minètų tyrimų galima daryti išvadą, kad galimybè skirtingai interpretuoti subsidiarumo sąvokos turini - yra patogi priemoné politiniams kompromisams siekti, kas skatina tolesni šio principo ES teisèje naudojimą, bet kartu programuoja nuolatinius ginčus dèl jo sampratos ir "tai nèra vien intelektualinè problema“73, greičiau nenoras aiškiai ir nedviprasmiškai jị apibrèžti. Galima teigti ir tai, kad be subsidiarumo principo valstybės narès nebegali apseiti, nes vieniems jis didesnio integralumo ir sutelkto ES veikimo priemoné sprendimų veiksmingumui pasiekti, kitiems - gynybos instrumentas valstybių narių pirmumo (prigimtinei) teisei išsaugoti, reikalaujantis sprendimus priimti arčiau piliečių.

\section{Išvados}

1. Iš pateiktos analizès matyti, kad skirtingas visuomenių mentalitetas, etinès ir socialinès vertybès (nulemtos ankstesnių bendruomenès būties formų) turèjo įtakos visuomenių socialiniam susitvarkymui ir skirtingų civilizacijų atsiradimui. Visuomenès organizavimo principai (iš jų reikšmingiausiu Vakarų socialinès sistemos struktūravimui laikytinas subsidiarumo principas), atsiradę antikos ir Romos imperijos miestuose, veikiami Vakarų ir Rytų kultūros, religijos ir teisès tradicijų, paskatino skirtingų socialinių sistemų (nacionalinių valstybių) atsiradimą ne tik Europoje, bet ir kitose pasaulio civilizacijose.

2. Subsidiarumo principas (kildintinas iš Vakaru visuomenès) yra tas teisinio reguliavimo instrumentas, kuriuo socialineje bendruomeneje institucionalizuojamos visuo-

69 Valstybės narès, įtvirtindamos ES sutartyje subsidiarumo principą, bandè juo remiantis spręsti joms rūpimus klausimus, pvz., Britanija rūpinosi didesniu valstybės suvereniteto išsaugojimu, Vokietija, pabrèždama sprendimų prièmimą problemos kilimo vietoje, siekè patenkinti Vokietijos žemių norus išsaugoti teisę vietos bendruomenėms pačioms spręsti savo problemas. De Bursa, G. Reappraising Subsidiarity’s Significance After Amsterdam. Cambridge, MA: Harvard Law School, Harvard Jean Monnet Working Pater 7/99, 1999.

70 Gomcijan, S. V., supra note 66, p. 59.

71 Blichner, L.; Sangolt, L. The concept of subsidiarity and the debate on European Cooperation: Pitfalls and Possibilities//Governance. 1994, 7 (3): 289.

72 Kondratienè, V., supra note 4.

73 Šiaudvytienè, E. Europos Sajungos subsidiarumo principo paradoksai. (I) [interaktyvus]. Vilnius: Všt „Bernardinai.lt“ 2009 [žiūrèta 2013-07-27]. <http://www.bernardinai.lt/straipsnis/2009-01-29-elena-siaudvytiene-europos-sajungos-subsidiarumo-principo-paradoksai-ii/3358\#form>. 
menès vertybinès nuostatos ir socialinès būties poreikiai. Subsidiarumo principo taikymo koncepcija valstybių organizacijose skiriasi tuo, kad konfederacijoje jis padeda išlaikyti ją sudarančių valstybių narių disponavimo valdžios galia prioritetą konfederacijos centrinių institucijų atžvilgiu, federacijoje - subalansuoja federalinės valdžios ir federacijos subjektų ịgaliojimus ir teisinę jų padètį, unitarinėje valstybèje - jis padeda sumažinti centrinès valdžios galios koncentraciją, dali jos perkeliant į žemesnị valdymo lygi. Taigi subsidiarumas yra veiksmingas valdymo galių balansavimo instrumentas, padedantis išvengti per didelès galios koncentracijos bet kurioje socialinèje organizacijoje ir bet kuriame valdžios galia disponuojančiame institute. Subsidiarumo principo paskirtis - įtvirtinti konstitucinę socialinio darinio sandaros formą atitinkantị valdžios galių paskirstymą ji sudarantiems subjektams.

3. Subsidiarumo principo institucionalizavimas valstybès valdyme - tai ígaliojimų skirtingo lygmens institucijoms paskirstymas, leidžiantis pasiekti sprendimų poveikio atitikties problemų mastui pusiausvyrą, kitaip tariant, užtikrinti priimamų sprendimų maksimalų veiksmingumą visuose valstybès valdymo grandyse. Šiuolaikinėse valdymo sistemose šis principas yra laikomas veiksmingu instrumentu sprendimams žemesniu nei valstybinis, bet aukštesniu nei vietinis valdymo lygmuo priimti, tuo sukuriant realias prielaidas regioninei dimensijai valstybės teritorinėje-administracinèje sistemoje îtvirtinti. Regioninio lygmens valstybès valdymo sistemoje institucionalizavimas grindžiamas tolygios (subalansuotos) krašto teritorinès plètros poreikiu bei regioną atitinkančios politikos ịgyvendinimu.

4. Subsidiarumo idejjos populiarumas Europoje grindžiamas tuo, kad ,subsidiarumas iškyla kaip politinè ir humanistinè idèja, etinè ir socialinė vertybè, turinti ilgametę Europos politinès minties tradiciją“, kuria remiantis kiekviena socialinè bendruomenè yra pajëgi išspręsti kylančias problemas, ịveikti nesutarimus ir pasiekti interesų pusiausvyrą. Subsidiarumo giluminès prasmès ir vertybinès reikšmès socialiniam visuomenès susitvarkymui suvokimas pastūmėjo Europos valstybių bendruomenes pasiremti subsidiarumo idèja didèjančio nacionalinio susipriešinimo Europoje laikmečiu (XX m. pradžia, taip pat laikotarpis po Antrojo pasaulinio karo) ir kurti Europos saugumą ir taikų žmonių bendrabūvị skatinančias struktūras.

5. Subsidiarumas pagristai laikomas universaliu procesų, sistemų ir santykių reguliavimo instrumentu. Remiantis šio fundamentaliu integracijos principu buvo ịsteigta Europos Sajunga, kurios atsiradimas paskatino valstybių teritorijų atvirumą, modernių visuomenès plètros koncepcijų, regionų, ekonominès veiklos bei socialinès infrastruktūros centrų kūrimą. Sparti teisinių ir ekonominių sistemų integracija leido naujai ịvertinti vieningos organizacijos galimybes sprendžiant Europos Bendrijos piliečių socialines-ekonomines problemas ir pasirinkti savitą Europos socialinị modelị, kuriame „socialiai orientuota rinkos ekonomika“ kaip „,kapitalo ir darbo priešpriešos ịveikos išraiška“ tapo Vakarų Europos valstybių socialine realybe, o daugelyje Rytų ir Vidurio Europos valstybių - socialine siekiamybe, reikalaujančia ne tik ekonominès sistemos pertvarkymų, bet ir visuomenès teisinès sąmonès pokyčių. 


\section{Literatūra}

Andrijauskas, A. Metacivilizacinès kultūros metamorfozès ir globalizacijos prieštaravimai. Logos. Religijos, filosofijos ir meno žurnalas. 2001, 25.

Akhiezer, A. C. Rossija: Kritika istoricheskogo opyta (sociokulturnaja dinamika Rossii) [Russia: Critique of the historical experience (Russia's sociocultural dynamics)]. T. 2. Teorija i metodologija: Slovar. Novosibirsk: Sibirskij khronograf, 1998.

Astrauskas, R. Etninès kultūros subjektų teisių apsauga. Etniné kultūra. 2004, 3.

Baglaj, M. V.; Lejbo, Ju. I.; Ehntin, L. M. Konstitucionnoe pravo zarubezhnykh stran [Constitutional law in foreign countries]. Moskva: NORMA, 2004.

Blichner, L.; Sangolt, L. The concept of subsidiarity and the debate on European Cooperation: Pitfalls and Possibilities. Governance. 1994: 7(3).

Bolshakov, S. N. Princip subsidiarnosti v sovremennom demokraticheskom upravlenii: konceptualnye podkhody $i$ problemy prakticheskoj realizacii [The principle of subsidiarity in modern democratic management: conceptual approaches and problems of practical implementation]. Dis. D-ra polit. 2006, s. 372 [interactive]. <www. lib.ua-ru.net/diss/cont/188411.html>.

Cairns, W. Europos Sajungos teisès ìvadas. Vilnius: Eugrimas, 1999.

Centr - regiony - mestnoe upravlenie [Center - regions - local authorities]. Pod red. Liuskhterkhandt-Mikhajlovoj, G. M.; Rizhinkova, S. I. Sankt-Peterburg, 2001.

Chagnollaund, D. Droit contemporain. tome 1, 4e edition, Paris: Armmand Colin, 2005.

Domas Cesevičius. Parengè V. Lukoševičius ir M. Treinys. Vilnius: Margi raštai, 1998.

Donskis, L. Kuo skiriasi lyginamujų civilizacinių studijų klasikai ir jų dabartinè banga. Baltos lankos. 1995, 6.
Endo, K. Subsidiarity and Its Enemies: To What: To What Extent Is Sovereignty Contested in the Mixed Common wealth of Europe? Florence: EUI, RSC Working Paper No. 2001/24, 2001.

Europos lëšos ir patirtis - šansas kiekvienam regionui. Vilnius, 2000.

Europos Sajunga steigimo dokumentu rinktine. Vilnius: Eugrimas, 1998.

Europos Sajungos sutarties ir Sutarties dèl Europos Sajungos veikimo suvestinès redakcijos [interaktyvus]. <http://eur-lex.europa.eu/ LexUriServ/LexUriServ.do?uri=OJ:C:2010: 083:FULL:LT:PDF>.

Europos socialinè chartija [interaktyvus]. <eurlex.europa.eu/.../-C2007303LT.01001701. $\mathrm{htm}>$.

Gaižiūnas, J. Nacijos tapsmas: lietuviu tauta istorijos ir dabarties kryžkelèse. Vilnius: Periodikos, 1990.

Gomcjan, S. V. Dinamika razvitija principa subsidiarnosti $v$ Evropejskom sojuze [Subsidiarity principle development dynamics in the European Union], Vestnik mezhdunarodnykh organizacij. 2007: 6(14).

Huntington, S. P. The Clash of Civilizations and the Remaking of World Order. New York, Simon \& Schuster, 1996.

Ilin, V. V.; Akhiezer, A. Rossijskaja civilizacija: soderzhanie, granicy, vozmozhnosti [Ilin, V. V.; Akhiezer, A. Russian civilization: content, boundaries, possibilities]. Moskva: Izd-tvo MGU, 2000.

Kirdina, S. G. Institucionalnye matricy $i$ razvitie Rossii [Institutional matrices and development of Russia]. Moskva: TEIS, 2000.

Kondratienè, V. Lietuvos regioninè politika Europos patirties kontekste. Lietuvos regionine politika ir teritorines sandaros tobulinimo problema. $2004 \mathrm{~m}$. balandžio 14 d. konferencijos medžiaga. Vilnius: Mykolo Romerio universitetas, 2004. 
Kondratienè, V. Lietuvos valstybès regioninè politika ir valstybės valdymas atsižvelgiant i Europos patirtį. Justitia. 2003, 6 (48).

Kondratiene, V. Subsidiarumo principas ir jo taikymas valstybes valdymui ir vietos savivaldai. Daktaro disertacija. Socialiniai mokslai, teisè. Vilnius: Mykolo Romerio universitetas, 2011.

Kondratienè, V. Teisiniai socialinių sistemų institucionalizavimo aspektai. Viě̌asis administravimas. 2012, 2 (34).

Kostjuk, K. Byt li Rossii subsidiarnoj? [Will Russia become a subsidiary state?] 2004 [interaktyvus]. <www.novopol.ru/-byit-lirossii-subsidiarnoy--text308.html>.

Kultūros ir civilizacijos analize [interaktyvus]. $<$ http://www.mokslai.lt/referatai/kursinis/1788.html $>$.

Lietuvos Respublikos teritorijos administracinių vienetų ir jų ribų įstatymas. Valstybès žinios. 1994, Nr. 60-1183; 2004, Nr. 1354893; 2010, Nr. 41-1934.

Mastrichto sutartis [interaktyvus]. <http:// ec.europa.eu/lietuva/abc_of_the_eu/-eu_ law/index_lt.htm>.

Melnikas, B. Regionalizmo procesai globalizacijos sąlygomis. Viešasis administravimas. 2011, 3 (31).

Merkel, A. Europos vertybės globaliame pasaulyje. Naujasis Židinys - Aidai. 2006, 1-2.

Nef, R. Da zdravstvuet noncentralizm! [Long live non-centralism!]: [Per.s. nem. / Robert Nef ; Friedrich Naumann Stiftung. Moskva: MAKS-press: Fond F. Naumanna, 2002 [interactive]. <www.libinst.ch/publikationen/ LI-Nef-Non-Zentralismus-ru.pdf $>$.

Pavilionis, Ž. Europos integracija ir civilizaciju susidūrimas. Politologija. 1999, 1(13).

Reappraising Subsidiarity's Significance After Amsterdam, Cambridge, MA: Harvard Law School, Harvard Jean Monnet Working Pater 7/99, 1999.

Romanenko, L. M. Socialnye technologii razreshenija konfliktov grazhdanskogo obshhestva: Ehkzistencialnye alternativy sovremennoj Rossii na poroge tretego tysjacheletija [Social technologies in civil community conflict resolution: Existential alternatives in contemporary Russia on the brink of the third millennium]. Moskva: Centr konfliktologii In-ta sociologii RAN, 1998.

Romeris, M. Unitarine valstybe ir valstybiniai junginiai. Vilnius: Justitia, 2008, pabaiga p. XXI.

Šiaudvytienè, E. Europos Sajungos subsidiarumo principo paradoksai. (I) [interaktyvus]. Vilnius: Všt „Bernardinai.lt“ 2009 $<$ http://www.bernardinai.lt/straipsnis/200901-29-elena-siaudvytiene-europos-sajungos-subsidiarumo-principo-paradoksaiii/3358\#form>.

Spinelli, A.; Rossi, E. The Ventotene Manifesto. Reader on the History and Theory of the European Integration. Part I. Compiled by M. Larionova, State University Higher School of Economics. European Markets after 1992. Ed. by Timothy M. Devinney, William C. Hightower. Lexington, Mass.: Lexington Books, 1991.

Tarptautiniu žodžiu žodynas. Sudarytoja V. Vaitkevičiūtè. Vilnius: Vyriausioji enciklopedijų redakcija, 2004.

Terin, D. F. "Zapad” $i$ “Vostok" v institucionalnom podkhode $k$ civilizacii ["West" and "East" institutional approach to civilisation]. Sociologicheskij zhurnal, 2001 [interaktyvus]. $\quad<$ http://www.nir.ru/Socio/-scipubl/sj/ sj4-01ter.html>.

Tiriakian, E. A. Reflekctions on the Sociology of Civilizations. Sociological Analysis. 1974, 35.

Toynbee, A. A Study of History / Abridgment of vol. I-VI by D. C. Somervell. New York: Oxford University Press, 1957.

Usher, J. A. Bendrieji Europos Bendrijos teisés principai. Vilnius: Naujoji Rosma, 2001. Vyriausiojo redaktoriaus ịžanga.

Europos Sajunga: enciklopedinis žinynas. Sudarytojas G. Vitkus. Vilnius: Eugrimas, 2002. 


\section{SUBSIDIARITY PRINCIPLE AS THE MEANS OF PERCEPTION OF THE IDENTITY OF THE CIVILIZATIONS}

\section{Virginija Kondratienè}

Summary. The paper discusses the importance of the subsidiarity principle to the regulation of the global processes. It also analyzes the role of the subsidiary principle as a fundamental principle of the European Union legal framework in the perception of the identity of the civilizations as well as its influence on political-legal systems. Not only does the paper emphasize the importance of this principle to the European identity, but it also discloses the role of the idea of the subsidiarity, which was played in legal and social consciousness of the communities attributed to the Western and Eastern civilizations. The principle of subsidiarity is used here as a tool to disclose the identity of the civilisations and differences among them. Simultaneously, its positive role is highlighted in the global community's solution of different kinds of conflicts (ideological, economic, religious or cultural) that arise among nations, countries or different civilisations. This article is aimed to demonstrante that reception of the principle of subsidiarity and it's institutionalization in the European Union and national legal frameworks are not accidental. The tools of legislative regulation based on this principle prevent global system from disregarding cultural differences. At the same time, it does not allow local identity to destroy the world unity. Thus, unified social systems can perfectly coexist with national, regional and local units, the latter ones maintaining their organizational structure and cultural traditions. Subsidiarity idea combining opposites makes sense as a principle of creating this diversity in unity, which ensures the integrity of autonomous structures making up the whole, preserving national, regional and cultural specificities of countries and people around the globe. The support of these processes provides the public with the opportunity to discover effective forms for the realization of self-organization and implementation of their needs and developing appropriate social structures and legal institutions regulating their activity. Through the examination of the concept of subsidiarity and aspects of its practical application in organizations, the article discusses the polarities of the different structure and management forms of the institutionalization of the principle of subsidiarity in the countries and its effect in the formation of the governance levels in the state, showing how balance of powers is achieved based on the subsidiarity principle, creating an effective mechanism of function distribution (determination of exclusive competencies) and their implementation (institutional interaction, their operational control). In structuring the institutional systems of the organization of the state, the subsidiarity concept is complemented with the elements of the management system decentralization, democratization, federalism and regional and local self-governments.

Keywords: civilization differences, Europe's identity, the principle subsidiarity, the legal regulation of social systems.

Virginija Kondratienė, Kazimiero Simonavičiaus universiteto Teisės fakulteto Teisės katedros docentè, socialinių mokslų daktarè. Mokslinių tyrinèjimų kryptys: teisès teorija, konstitucinè teisè, administracinè teisè, Europos Sajungos teisè, savivaldos teisès, parlamentinè kontrolè.

Virginija Kondratienė, Kazimieras Simonavičius University, Faculty of Law, Department of Law, Assoc Prof Dr. Research interests: legal theory, constitutional law, administrative law, European Union law, municipal law, parliamentary control. 